\title{
LAND FRAGMENTATION AND ITS DETERMINANTS IN NIGERIA: A CASE STUDY OF SMALLHOLDER FARMERS IN IKENNE AGRICULTURAL ZONE, OGUN STATE, NIGERIA
}

\author{
Abiodun Elijah Obayelu ${ }^{1 \bowtie}$, Omotoso Oluseye Ogunmola ${ }^{1}$, \\ Kola Jeremiah Oyewole ${ }^{1}$ \\ ${ }^{1}$ Federal University of Agriculture Abeokuta, (FUNAAB), Ogun State, Nigeria
}

\begin{abstract}
Land fragmentation is a major obstacle to agricultural development in Nigeria. Therefore, the objective of this study is to examine land fragmentation and its determinants as seen by smallholder farmers in Ikenne Agricultural zone of Ogun State, Nigeria. A multistage sampling procedure was used to select 120 smallholder farmers in the study area. Descriptive statistics, Simmons index and Tobit Regression were used. The results of the Simmons index showed that the average land fragmentation index was 0.38 , implying that smallholder farmland is highly fragmented. The average annual household income $(p<0.01)$, labor force of household $(p<0.05)$, education level $(p<0.01)$ and land ownership $(p<0.1)$ were the significant factors that negatively influenced land fragmentation in the study area. However, the size of land rented in by household $(p<0.001)$ significantly increases the degree of land fragmentation. Therefore, land consolidation and application of specific land protection policies to prevent agricultural land from being developed for non-agricultural purposes are recommended.
\end{abstract}

Keywords: scattered plots, land plot, land parcel, land consolidation

\section{INTRODUCTION}

The sustainability of agriculture relies on nature, and depends on the availability of and accessibility to arable land. The importance of land to man cannot be underemphasized. It is a finite, non-reproducible natural resource of essential importance for the survival and upkeep of mankind and maintenance of all global ecosystems. It is also a form of wealth that can be transferred across generations (Akintayo and Lawal, 2016). Land is a major resource needed in agriculture which, if absent, makes other resources less useful. It serves as a basis for most agricultural operations (Apata, 2016). Although Nigeria is gifted with massive amounts of arable land, its agriculture is dominated by smallholder farmers with numerous small and dispersed farms. This can be attributed to land fragmentation which is a reasonable consequence of inheritance practices.

Cultivated land area is one of the major limited resources that farmers depend on for their living. Land fragmentation also known as pulverization, parcellization or scattering (Bentley, 1987) is a major factor hindering agricultural development in Nigeria and a key empirical question in Africa (Kiplimo and Ngeno, 2016). It was defined as a situation where a single farm consists of numerous spatially separated parcels (Van Dijk, 2003) / plots of land (Bentley, 1987; Kentaro, 2010) or a case where farmers operate two or more geographically separated tracts of land, taking account of the distances between those parcels (Bizimana et al., 2004). Some of the dominant problems associated with

\footnotetext{
$\llbracket$ Abiodun Elijah Obayelu, PhD, Department of Agricultural Economics and Farm Management, Federal University of Agriculture, PMB2240, Abeokuta, Ogun State, Nigeria, e-mail: obayelu@yahoo.com; https://orcid.org/0000-0003-3328-7717
} 
Obayelu, A. E., Ogunmola, O. O., Oyewole, K. J. (2019). Land fragmentation and its determinants in Nigeria: A case study of smallholder farmers in Ikenne Agricultural Zone, Ogun State, Nigeria. J. Agribus. Rural Dev., 2(52), 147-155. http://dx.doi. org/10.17306/J.JARD.2019.01135

land fragmentation is the small size, irregular shape, and dispersion of parcels (Demetriou et al., 2013; Gonzalez et al., 2017).

While land fragmentation is a known global phenomenon (Latruffe and Piet, 2014) or a universal feature affecting all agriculture systems (Alemu et al., 2017), it was found to play an important role in less developed agricultural systems (Blarel et al., 1992; Van Hung et al., 2007). Land fragmentation has been a persistent prominent phenomenon in several countries ever since at least the $17^{\text {th }}$ century (Tan et al., 2006). Fragmentation of landholdings has been referred to as a setback for agricultural development (Van Hung et al., 2007; Hristov, 2009) because it obstructs agricultural mechanization, causes inefficiencies in production, and requires huge costs to lessen its effects (Najafi, 2003; Thomas, 2007; Thapa, 2007; Tan et al., 2008). The menace of land fragmentation increases production costs, resulting in inefficient allocation of labor and capital inputs (Deininger et al., 2014; Tan, 2005). However, regarded from an opposite point of view, land fragmentation is believed to be a positive situation which allows farmers to cultivate many environmental zones, minimize production risks and optimize the schedule for cropping activities (Kadigi et al., 2017; Kakwagh et al., 2011; McPherson, 1982; Simpson, 1987). It also encourages farmers to cultivate a variety of crops of different maturity and ripening periods in order to focus and manage their labor use on different plots at different time, thereby avoiding household labor bottlenecks (Bentley, 1990). Challenges faced as a result of traditional land tenure system in $\mathrm{Ni}$ geria have been widely explained by some land experts (Olayiwola and Adeleye, 2006; Fabiyi, 1984). Some of the major causes of land fragmentation in Nigeria were identified as traditional land tenure system coupled with increasing population (Okezie et al., 2012), land markets, and historical cultural perspectives (Demetriou et al., 2013). This has attendant consequences for agricultural productivity and commercialization. While research revealed the existence of land fragmentation in Nigeria, there is no comparable data on land fragmentation. This inadequacy makes it difficult to identify the extent at which land fragmentation reached its limits. Understanding land fragmentation and its determinants based on an empirical approach will serve as a guide and a solution to key policy decisions in agriculture in Nigeria and Africa at large.

\section{REVIEW OF PREVIOUS STUDIES}

Wide explanations form literatures (Van Hung et al., 2007; Hristov, 2009; Najafi, 2003; Thomas, 2007; Thapa, 2007; Tan et al., 2008) have established extensively that land fragmentation is a serious problem for agricultural development. It thwarts agricultural mechanization as a result of the geographical distribution of parcels. It can cause inefficiencies and low productivity in agricultural production because it makes farmers unable to efficiently utilize their resources or inputs. And lastly, land fragmentation requires large costs to alleviate its effects. Therefore, the following questions need to be asked: what are the socioeconomic variables accounting for land fragmentation? To what extent does land fragmentation affect smallholder farmers? What are the factors responsible for land fragmentation among smallholder farmers? The following study has to be carried out to provide the answers. Therefore, the objectives of this paper were threefold. The first is to identify the socioeconomic variables responsible for land fragmentation. Second, the study estimated the extent of land fragmentation among smallholder farmers in the study area. Third, it examined the variables accounting for the effect of land fragmentation on farmers' production.

Previous studies and considerable literature have examined the relationship between land fragmentation, land productivity and efficiency at farm level (Blarel et al., 1992; Bizimana et al., 2004; Wu et al., 2005; Thomas, 2007; Van Hung et al., 2007; Rahman and Rahman, 2009; Chen et al., 2009; del Corral et al., 2011; Austin et al., 2012; Sauer et al., 2012). There are conflicting views on whether land fragmentation is problematic or not (Nguyen et al., 1996; Wu et al., 2005; Sklenicka et al., 2014; Sklenicka, 2016).

To begin with, some viewpoints see land fragmentation as the basis of ineffective agriculture (Bentley, 1990; Van Hung et al., 2007; Rahman and Rahman, 2008; Di Falco et al., 2010; Corral et al., 2011; Latruffe and Piet, 2014; Sklenicka et al., 2014; Apata, 2016). This is due to the fact that constant subdivision of farmland would lead to small-sized land holdings which may be tedious to operate on an economically sound basis. Land fragmentation was said to cause more harm than good to agricultural productivity in a number of ways. Fragmented land holdings can increase transport costs. It results in time wasting, especially when farmers have to travel between plots and their home (in a situation 
Obayelu, A. E., Ogunmola, O. O., Oyewole, K. J. (2019). Land fragmentation and its determinants in Nigeria: A case study of smallholder farmers in Ikenne Agricultural Zone, Ogun State, Nigeria. J. Agribus. Rural Dev., 2(52), 147-155. http://dx.doi. org/10.17306/J.JARD.2019.01135

when plots are located away from each other and from the farmer's home). Management, supervision and securing of scattered plots can also be more difficult, time consuming and costly. Small and scattered plots waste land area and require more efforts involved in fencing, border constructions, paths and roads. Land fragmentation might also increase the risk of disputes between neighbors (Mwebaza and Gaynor, 2002). Small fragmented land holdings might also cause difficulties to grow certain crops, and prevent farmers from shifting to high-profit crops. More profitable crops, such as fruits, require larger plot areas. Hence, if the farmers only possess small and fragmented plots, they may be forced to grow only less profitable crops (World Bank, 2005). There is limitation to the use of machinery and other large-scale agricultural practices. In small fields, operating machines and moving them from one field to another can cause problems. Small land holdings might also discourage the development of infrastructure like transportation, communication, irrigation and drainage (Mwebaza and Gaynor, 2002). Moreover, the financial institutions are sometimes reluctant to accept small and scattered land holdings as collateral, which inhibits farmers from obtaining investment loans (Mwebaza and Gaynor, 2002). Considering these detriments, land fragmentation is thus considered as a defect which has instigated several countries to enact land consolidation programs (Niroula and Thapa, 2005; World Bank, 2005; Sundqvist and Anderson, 2006; Van Hung et al., 2007).

Land fragmentation has reduced the sizes of farmland intended for agricultural practices (Akintayo and Lawal, 2016). These small-sized farms feature substandard operational levels, inexperienced or poorly literate operators, and expensive production technologies coupled with hired labor cost representing ca. 60 percent of total production costs (Olayemi, 1980; Aromolaran, 1992). Land fragmentation may affect the farmers' production decisions and management practices, and therefore may affect farming performance. The counter viewpoint sees land fragmentation as a positive scenario that enables farmers to cultivate many environmental zones, minimize production risks and optimize the schedule for cropping activities (Bentley, 1990). The acknowledged advantages of land fragmentation in this standpoint are closely related to the demand-side causes of fragmentation. One of the benefits associated with land fragmentation is the variety of soil and growing conditions that reduce the risk of total crop failure by giving the farmer a variety of soil and growing conditions. Many different plots allow farmers' access to land of different qualities in terms of soil, slope, microclimatic variations etc. Fields with high yields one year may generate much lower yields the following year; thus, several plots of the same crop also spread out the risk. Furthermore, a holding with several plots facilitates crop rotation and the ability to leave some land fallow (Bentley, 1990).

\section{METHODOLOGY}

\section{Study area}

This study was conducted in Ogun State, one of the six states in the Southwest geopolitical zone of Nigeria. One of the ancient states of the nation, it is well known for agricultural practices. Ogun State is located between latitudes $6^{\circ} 54.59^{\prime} \mathrm{N}$ and longitudes $3^{\circ} 15.50 \mathrm{E}$, with a population of 103,261 and an area of 16,980.55 $\mathrm{km}^{2}$ (NPC, 2006). It has a relatively high humidity, with average daily temperatures ranging between $25^{\circ} \mathrm{C}\left(77^{\circ} \mathrm{F}\right)$ and $29^{\circ} \mathrm{C}$ $\left(84^{\circ} \mathrm{F}\right)$ almost all year round (Weather2, 2017). Ogun State enjoys abundant rainfall of over $1500 \mathrm{~mm}$ annually; south-westerly winds blow over the LGA during most of the year. The climate in the local government area favors the cultivation of crops like rice, maize, cassava, yam and banana. The study area is well known for the cultivation of crops and rearing of animals as the population's main occupation, the other being blacksmithing, carpentry, hairdressing, tailoring, trading etc.

\section{Sampling procedure and sample size}

The population surveyed comprises the smallholder farmers in the study area. A multistage sampling procedure was used to select 120 respondents. The first stage was the purposive selection of Ikenne Agricultural Zone. According to the distribution of agricultural zones by OGADEP, Ikenne Agricultural Zone is one of the four zones in Ogun State, and is predominantly known for rice production. The second stage was the purposive selection of Obafemi block from the four blocks in the zone (Isara, Simawa, Someke and Obafemi) based on the OGADEP's distribution by agro-ecological features. In the third stage, six cells in Obafemi block were randomly selected (these are Obafemi, Ajebo, Kajola, Aiyerose, Ogunmakin and Adigbe). The fourth stage was the selection of twenty (20) smallholder farmers from each of the 6 cells using a simple random sampling technique, making a total sample size of 120 respondents. 

smallholder farmers in Ikenne Agricultural Zone, Ogun State, Nigeria. J. Agribus. Rural Dev., 2(52), 147-155. http://dx.doi. org/10.17306/J.JARD.2019.01135

\section{Data collection and analytical technique} Primary data was collected from the farmers through a hardcopy questionnaire complemented by interviews. Though conducted in English, the interviews were interpreted to respondents in their local languages to enable a better understanding when required. Adequate precautions were put in place to avoid the respondent's discomfort to participate in the interview. Participants were pre-informed about the reason for the research and the potential benefits that may spring up. Everyone were given equal chances to eliminate the problem of biasness and to obtain best information from them. Also, the questionnaire was validated by administering ten copies to farmers located outside the study area. Once collected, the data was analyzed using descriptive and inferential statistics. The descriptive statistics (mean, standard deviation, minimum and maximum counts) were used to describe the socioeconomic characteristics of smallholder farmers, such as their plot size, farming experience, age, income and distribution of respondents by land fragmentation in the study area. The inferential statistics employed were the Simmons index to measure land fragmentation, and Tobit regression to analyze the determinants of land fragmentation.

\section{Measurement of land fragmentation}

There are six different factors generally used to measure the degree of land fragmentation: farm size, number of plots, plot size, plot shape, spatial distribution of plots, and the size distribution of plots. A common metric of fragmentation used in studies is the average number of plots per farm. In an attempt to standardize the fragmentation measures, the authors also use the index of fragmentation. The Simmons index used in this paper is defined as the sum of squares of plot areas divided by the square of farm area (Tan, 2005).

\section{Simmons index}

The Simmons index was used to estimate the degree of land fragmentation in this study. The method was adopted from Simmons (1964) who took into account the number of parcels in a holding and the relative size of each parcel. The model for the Simmons index is stated in Equation 1.

$$
\mathrm{SI}=\frac{\sum_{i=1}^{n} a_{i}^{2}}{\sum_{i=1}^{n} A_{i}^{2}}
$$

where:

$\mathrm{SI}$ - is the fragmentation index

$n$ - is the number of farms belonging to each individual farmer

$a-$ is the size of each fragmented farm

$A$ - is the total cultivated farm area.

The index has a value between 0 and 1 . A value of 1 corresponds to complete land consolidation, i.e. to a farm which operates with only one parcel. Conversely, a value of 0 means the farm is very fragmented and operates a large number of plots. This index is sensitive to the number and size of plots, which means that fragmentation decreases as the area of the big plots increases, for example (Tan, 2005; Van Hung et al., 2005).

\section{Tobit regression model}

The Tobit regression model was used to estimate the factors influencing land fragmentation among smallscale farmers in the study area. It allows to examine the effects of a number of variables on the underlying probability of a dependent variable. The model helps predicting the likelihood that a farmer will be exposed to land fragmentation, given a set of related factors. The variables were carefully selected based on theories and empirical literature regarding factors that could influence land fragmentation. When it comes to land fragmentation, the dependent variable in the estimated model was set to be the degree of land fragmentation. The model is explicitly stated as:

$$
\begin{aligned}
y i^{*}= & b_{0}+b_{1} X_{1}+b_{2} X_{2}+b_{3} X_{3}+b_{4} X_{4}+b_{5} X_{5}+ \\
& +b_{6} X_{6}+b_{7} X_{7}+b_{8} X_{8}+b_{9} X_{9}+e_{\mathrm{o}}
\end{aligned}
$$

$$
i=1,2,3 \ldots n
$$

where:

$y i^{*}-$ degree of land fragmentation (index)

$X_{i}-$ set of explanatory variables.

The independent variables were specified as follows: $X_{1}$ - average annual household income (NGN/USD equivalent value)

$X_{2}$ - Per capita arable land area (ha)

$X_{3}$ - Size of land rented in by household (ha)

$X_{4}$ - Size of land rented out by household (ha)

$X_{5}$ - Labor force of household (man-day)

$X_{6}-$ Number of crops cultivated by household (number)

$X_{7}-$ Farming experience (years)

$X_{8}$ - Education level (years) 
Obayelu, A. E., Ogunmola, O. O., Oyewole, K. J. (2019). Land fragmentation and its determinants in Nigeria: A case study of smallholder farmers in Ikenne Agricultural Zone, Ogun State, Nigeria. J. Agribus. Rural Dev., 2(52), 147-155. http://dx.doi. org/10.17306/J.JARD.2019.01135

$X_{9}$ - Farm ownership (1 if land owner, 0 if tenant)

$\beta$-Coefficients that were estimated

$e_{\mathrm{o}}$ - Independently distributed error term

\section{RESULTS AND DISCUSSION}

\section{Description of socioeconomic variables of respondents}

The descriptive characteristics of the farmers interviewed are presented in Table 1 as a simple summary of the samples and measures. The number of plots cultivated by households range from 1 to 4 , with an average of 2.49. The average plot area varies in the range of 0.50 to 7 ha, with an average of 1.69 ha. The average family size is 7.15 people, with an average of ca. $68.32 \%$ of household members belonging to labor force. The average size of land rented in by the households is 1.12 ha, which is significantly larger than the average size of land rented out (0.68 ha). The share of the households' off-farm income (37.12\%) reveals their active involvement in off-farm employment. However, the average annual household income ranges from NGN 264,000 (USD 735.38) to NGN 3,036,000 (USD 8,456.82), with an average of NGN 900,350 (USD 2,507.94). The farmers' average age and experience in agricultural activities were 45.78 and 15.75 years, respectively. The table also revealed that the number of crops cultivated by farmers varies from 1 to 5 , with an average of 2.43 which is characteristic of subsistence rather than commercial farming. The above corroborates the research by Kalantari and Abdollahzadeh (2008). The total available land size for the households is 4.75 ha out of which 0.76 ha is available arable cultivation. The average distance of farmland to main water source, village center and main road is $15.65 \mathrm{~km}, 15.87 \mathrm{~km}$ and $9.22 \mathrm{~km}$, respectively.

Table 1. Summary statistics of socioeconomic variables of respondents

\begin{tabular}{lcccc}
\hline \multicolumn{1}{c}{ Variables } & Mean & Std. dev. & Minimum & Maximum \\
\hline Number of plots cultivated by household & 2.49 & 0.98 & 1.00 & 4.00 \\
Plot size (ha) & 1.69 & 1.29 & 0.50 & 7.00 \\
Family size (number of people) & 7.15 & 2.84 & 1.00 & 13.00 \\
Size of land rented in by household & 1.12 & 0.97 & 0.00 & 3.18 \\
Size of land rented out by household & 0.68 & 0.43 & 0.00 & 2.43 \\
Share of off-farm income (percent) & 37.12 & 19.85 & 7.10 & 92.67 \\
Average annual household income (NGN/USD thousand) & 900.35 & 657.19 & 264.00 & 3036.00 \\
& $($ USD 2.508$)$ & & $($ USD 0.735$)$ & $($ USD 8.457$)$ \\
Farming experience (years) & 15.75 & 6.19 & 2.00 & 32.00 \\
Age of landholders & 45.78 & 10.51 & 26.00 & 71.00 \\
Number of crops cultivated by household & 2.43 & 1.04 & 1.00 & 5.00 \\
Total available land area (ha) & 4.75 & 2.90 & 1.50 & 13.00 \\
Per capita arable land area (ha) & 0.76 & 0.62 & 0.12 & 3.25 \\
Labor force of household (percent) & 68.32 & 33.47 & 9.12 & 98.86 \\
Average distance between farmland and main water source (km) & 15.65 & 5.79 & 3.45 & 46.23 \\
Average distance between farmland and village center (km) & 15.87 & 6.11 & 1.50 & 25.55 \\
Average distance between farmland and main road (km) & 9.22 & 4.89 & 0.50 & 26.21 \\
\hline
\end{tabular}

Note: NGN $1 \approx$ USD 0.00359 as at January 2017 when the data was collected.

Source: field survey, 2017. 
Obayelu, A. E., Ogunmola, O. O., Oyewole, K. J. (2019). Land fragmentation and its determinants in Nigeria: A case study of smallholder farmers in Ikenne Agricultural Zone, Ogun State, Nigeria. J. Agribus. Rural Dev., 2(52), 147-155. http://dx.doi. org/10.17306/J.JARD.2019.01135

Table 2. Distribution of respondents by land fragmentation

\begin{tabular}{lcccc}
\hline \multicolumn{1}{c}{ Simmons index } & Frequency & Percentage & Mean farm size & $\begin{array}{c}\text { Mean fragmentation } \\
\text { index }\end{array}$ \\
\hline $0.01-0.20$ & 7 & 5.8 & 3.75 & 0.16 \\
$0.21-0.40$ & 76 & 63.3 & 4.82 & 0.29 \\
$0.41-0.60$ & 21 & 17.5 & 5.69 & 0.45 \\
$0.61-0.80$ & 12 & 10 & 3.79 & 0.73 \\
$0.81-0.99$ & 3 & 2.5 & 3.50 & 0.83 \\
1 & 1 & 0.8 & 3.00 & 1.00 \\
Total & 120 & 100 & 4.75 & 0.378 \\
\hline Fragmentation degree & Frequency & Percentage & & \\
\hline High (0-0.49) & 82 & 69.1 & & \\
Low (0.50-0.99) & 36 & 30 & & \\
Land consolidation (1) & 2 & 0.9 & \\
\hline
\end{tabular}

Source: field survey, 2017.

\section{Distribution of respondents by degree of land fragmentation}

The Simmons index propounded by Simmons was used to analyze the degree of land fragmentation of the respondents' farms. The results highlighted in Table 2 show that most $(63.3 \%)$ rice farmers have a Simmons index of between 0.21 and 0.40 . A Simmons index of 1 was recorded for a small proportion of them $(0.8 \%)$. Judging by the decision rule of the Simmons index, a total of $69.1 \%$ of respondents experience a high degree of land fragmentation as their Simmons values are close to zero (Tan, 2005). Furthermore, ca. 30\% of the farmers have a Simmons index close to one which implies a lower degree of land fragmentation while $0.9 \%$ of the respondents have a Simmons index of 1, implying a complete consolidation (Tan, 2005; Austin et al., 2012).

\section{Results of Tobit regression analysis for the factors influencing land fragmentation}

The results shown in Table 3 reveal the significant variables that influence land fragmentation in the study area. As shown by the Tobit regression model, the average annual household income $(p<0.01)$, size of land rented in by household ( $p<0.001)$, labor force of household $(p<0.05)$, education level $(p<0.01)$ and land ownership $(p<0.1)$ were the significant factors influencing land fragmentation in the study area. The result shows a negative relationship between the average annual household income and degree of land fragmentation, indicating that the higher the amount of income earned by the household, the lower the degree of land fragmentation. Higher and stable incomes will enable the farmers to limit the numbers of plots for cultivation and focus on cultivating consolidated land. The positive relationship between the area of land rented in by the household and the degree of land fragmentation indicates that farmers tend to increase the number of plots used for cultivation as they acquire larger parcels or holdings for themselves. The acquisition of many plots or holdings may drive increased fragmentation but it may also allow the farmer to operate large acreages.

Also, the negative relationship between the household's labor force and the degree of land fragmentation shows that the degree of land fragmentation decreases with an increase in labor use. This can be explained by the improved ability to make use of available labor resources for production purposes. The negative relationship between educational level of small-scale farmers and the degree of land fragmentation explains the extent of exposure to the negative effects land fragmentation has on agricultural productivity. Thus, the higher the educational level of a farmer, the more likely he/ 
Obayelu, A. E., Ogunmola, O. O., Oyewole, K. J. (2019). Land fragmentation and its determinants in Nigeria: A case study of smallholder farmers in Ikenne Agricultural Zone, Ogun State, Nigeria. J. Agribus. Rural Dev., 2(52), 147-155. http://dx.doi. org/10.17306/J.JARD.2019.01135

Table 3. Factors influencing land fragmentation

\begin{tabular}{lllc}
\hline \multicolumn{1}{c}{ Variable } & Coefficient & $t$-value & $p$-value \\
\hline Average annual household income & $-2.93 \mathrm{E}-07^{* * * *}$ & -3.78 & 0.000 \\
Per capita arable land area & 0.017 & 0.21 & 0.834 \\
Size of land rented in by household & $0.079^{* * *}$ & 3.64 & 0.000 \\
Size of land rented out by household & -0.007 & -0.77 & 0.441 \\
Labor force of household & $-0.001^{* *}$ & -2.06 & 0.042 \\
Number of crops cultivated by household & -0.021 & -1.48 & 0.141 \\
Farming experience & 0.002 & 0.83 & 0.408 \\
Education level & $-0.023^{* * *}$ & -3.04 & 0.001 \\
Farm ownership & $-0.086^{*}$ & -1.95 & 0.054 \\
Constant & $0.809^{* * *}$ & 5.74 & 0.000 \\
Log pseudo likelihood & 51.34738 & & \\
LR chi ${ }^{2}$ (9) & 31.51 & & \\
Prob $>$ F & 0.0002 & & \\
\hline
\end{tabular}

$*, * *$ and $* * *$ denote statistical significance at $10 \%, 5 \%$ and $1 \%$, respectively.

Source: field survey, 2017.

she would be to reduce the number of plots/holdings for cultivation, thus reducing the degree of land fragmentation. This is in line with the findings of Tumer et al. (2010). The above results could also be explained by the fact that a farmer who gains formal education can critically analyze the situation and make his/her own decisions (Caleb and Ramatu, 2013). Farm ownership was statistically significant and had a negative influence on the degree of land fragmentation experienced by the farmer. Thus, the larger the area of land owned, the less likely it is for the farmer to experience land fragmentation. Based on the results, it can be concluded that as the area of owned land increases, the probability of land fragmentation goes down.

\section{CONCLUSION AND RECOMMENDATIONS}

The study concludes that the majority of respondents in the study area own fragmented, geographically dispersed farms. This study represents a step forward from previous research on land fragmentation in Nigeria by providing a more detailed analysis of the processes underlying land fragmentation and by using available rural socio-economic observation data from Ikenne Agricultural zone of Ogun State to obtain empirical estimates of major determinants of land fragmentation in Nigeria. The results showed that the average annual household income is an important determinant for both the number of plots and the average plot size. As expected, the share of labor force members in a household also plays a role in land fragmentation. As shown by the results, when the share of labor force increases by 1 unit, the number of plots changes by more than the average plot size. In turn, the regression model suggests that households with a higher average annual income, adequate labor force, higher education level and larger area of own land tend to reduce the degree of land fragmentation in the study area. However, those with a larger area of land rented in increase the degree of land fragmentation. Land fragmentation should not be considered as undesirable; it should also not be viewed as purely originating from a single factor. Land consolidation and application of specific land protection policies/programs to prevent agricultural land from being developed for non-agricultural purposes are recommended. Also, this paper calls for support for small-scale farmers by providing functional, practical, and productive education as well as subsidies for land purchase. 
Obayelu, A. E., Ogunmola, O. O., Oyewole, K. J. (2019). Land fragmentation and its determinants in Nigeria: A case study of smallholder farmers in Ikenne Agricultural Zone, Ogun State, Nigeria. J. Agribus. Rural Dev., 2(52), 147-155. http://dx.doi. org/10.17306/J.JARD.2019.01135

\section{REFERENCES}

Akintayo, O. I., Lawal, B. O. (2016). Effect of Land Fragmentation on Technical Efficiency Among Farmers In Southwest Nigeria. Int. J. Sci. Nature, 7(3), 2016, 487-491.

Alemu, G. T., Ayele, Z. B., Berhanu, A. A. (2017). Effects of land fragmentation on productivity in northwestern Ethiopia. Adv. Agric., Retrieved from: https://doi.org/10.1155/ $2017 / 4509605$

Apata, T. (2016). Small farms and agricultural productivity in Nigeria: empirical analysis of the effects of land tenure, fragmentation and property rights. Acad. J. Agric. Res., 4(12), 691-697.

Aromolaran, A. B. (1992). Multiple objectives and resource allocation behavior of small farmers in Ifedapo Area of Oyo State, Nigeria. A Ph. D (Doctoral dissertation, Thesis in the Department of Agricultural Economics, University of Ibadan, Nigeria).

Austin, O. C., Ulunma, A. C., Sulaiman, J. (2012). Exploring the link between land fragmentation and agricultural productivity, Int. J. Agric. Forest., 2(1), 30-34.

Awotide, D. O., Agbola, P. O. (2010). Relationship between land fragmentation and maize farmers' productivity in northern Nigeria. J. Life Phys. Sci, 3, 1-9.

Bentley, W. (1987). Economic and ecological approaches to land fragmentation: In defence of a much-maligned phenomenon. Ann. Rev. Anthropol., 16, 31-67.

Bentley, J. W. (1990). Wouldn't you like to have all of your land in one place? land fragmentation in Northwest Portugal. Human Ecol., 18(1), 51-79.

Bizimana, C., Nieuwoudt, W. L., Ferrer, S. R. (2004), Farm size, land fragmentation and economic efficiency in southern Rwanda. Agrekon, 43(2), 244-262.

Blarel, B., Hazell, P., Place, F., Quiggin, J. (1992). The economics of farm fragmentation: evidence from Ghana and Rwanda. World Bank Econ. Rev., 6(2), 233-254.

Caleb, D., Ramatu, A. (2013). Factors influencing participation in rice development projects: the case of smallholder rice farmers in Northern Ghana. Int. J. Dev. Econ. Sustain., 1(2), 13-27.

Chen, Z., Huffman, W. E., Rozelle, S. (2009). Farm technology and technical efficiency: Evidence from four regions in China. China Econ. Rev., 20(2), 153-161.

Deininger, K., Monchuk, D., Nagarajan, H. K., Singh, S. K. (2014). Does Land Fragmentation Increase the Cost of Cultivation? Evidence from India. Policy Research Working Paper No. 7085. Washington: World Bank Group.

del Corral, J., Perez, J. A., Roibás, D. (2011). The impact of land fragmentation on milk production. J. Dairy Sci., 94(1), 517-525.
Demetriou, D., Stillwell, J., See, L. (2013). A new methodology for measuring land fragmentation. Comp. Env. Urban Syst., 39, 71-80.

Di Falco, S., Penov, I., Aleksiev, A., Van Rensburg, T. M. (2010). Agrobiodiversity, farm profits and land fragmentation: Evidence from Bulgaria. Land Use Policy, 27(3), 763-771.

Fabiyi, Y. L. (1984). Land Administration in Nigeria; Case studies of Implementation of land Use Decree (Act) in Ogun Ondo and Oyo State of Nigeria. Agric. Admin., 17(1), 21-31.

Gashaw, T. A., Zewdu, B. A., Assefa, A. B. (2017). Effects of Land Fragmentation on Productivity in Northwestern Ethiopia. Advan. Agric., 1-9. https://doi.org/10.1155/ 2017/4509605

Gonzalez, X. P., Marey, M. F., Alvarez, C. J. (2007). Evaluation of productive rural land patterns with joint regard to the size, shape and dispersion of plots. Agric. Syst., 92(1-3), 52-62.

Hristov, J. (2009). Assessment of the impact of high fragmented land upon the productivity and profitability of the farms - The case of the Macedonian vegetable growers. SLU, Department of Economics Thesis 561 Degree Thesis in Business Administration Uppsala.

Kadigi, R. M. J., Kashaigili, J. J., Sirima, A., Kamau, F., Sikira, A., Mbungu, W. (2017). Land fragmentation, agricultural productivity and implications for agricultural investments in the Southern Agricultural Growth Corridor of Tanzania (SAGCOT) region, Tanzania. J. Dev. Agric. Econ., 9(2), 26-36. doi: 10.5897/JDAE2016.0797

Kakwagh, V. V., Aderonmu, J. A., Ikwuba, A. (2011). Land fragmentation and agricultural development in tivland of Benue State, Nigeria. Curr. Res. J. Soc. Sci., 3(2), 54-58.

Kalantari, K., Abdollahzadeh, G. (2008). Factors affecting agricultural land fragmentation in Iran: a case study of Ramjerd Sub District in Fars Province. Am. J. Agric. Biol. Sci., 3(1), 358-363.

Kentaro, K. (2010). The costs and benefits of land fragmentation of rice farms in Japan. Austr. J. Agric. Res. Econ., 54(4), 508-526.

Kiplimo, L. B., Ngeno, V. (2016). Understanding the Effect of Land Fragmentation on Farm Level Efficiency: An Application of Quantile Regression-Based Thick Frontier Approach to Maize Production in Kenya. Invited paper presented at the $5^{\text {th }}$ International Conference of the African Association of Agricultural Economists, September 23-26, 2016, Addis Ababa, Ethiopia.

Latruffe, L., Piet, L. (2014). Does land fragmentation affect farm performance? A case study from Brittany, France. Agric. Syst., 129, 68-80. 
Obayelu, A. E., Ogunmola, O. O., Oyewole, K. J. (2019). Land fragmentation and its determinants in Nigeria: A case study of smallholder farmers in Ikenne Agricultural Zone, Ogun State, Nigeria. J. Agribus. Rural Dev., 2(52), 147-155. http://dx.doi. org/10.17306/J.JARD.2019.01135

McPherson, M. F. (1982). Land fragmentation: a selected literature review (No. 141). Harvard University, Harvard Institute for International Development.

Mwebaza, R., Gaynor, R. (2002). Land sector analysis; land market, land consolidation, and land re-adjustment component. Rural Development Institute, The Government of the Republic of Uganda.

Najafi, M. R. (2003). Watershed modelling of rainfall excess transformation into runoff. J. Hydrol., 270(3-4), 273-281.

Nguyen, T., Cheng, E., Findlay, C. (1996). Land fragmentation and farm productivity in China in the 1990s. China Econ. Rev., 7(2), 169-180.

Niroula, G. S., Thapa, G. B. (2005). Impacts and causes of land fragmentation, and lessons learned from land consolidation in South Asia. Land Use Policy, 22(4), 358-372.

Okezie, C. A., Ahuchuogu, C. U., Jamalludin, S. (2012). Exploring the Link between Land Fragmentation and Agricultural Productivity. Int. J. Agric. Forest., 2(1), 30-34. doi: 10.5923/j.ijaf.20120201.05

Olayemi, S. K. (1980). Food Crop Production by Small Farmers in Nigeria. In: S. O. Olabisi, J. A. Eweka, V. E. Bello Osagie (Eds.), Problems and Perspectives in Integrated Rural Development. Centre for Agricultural and Rural Development, University of Ibadan.

Olayiwola, L. M., Adeleye, O. (2006). Land reform-experience from Nigeria. In Proceeding of 5th FIG Regional Conference on Promoting Land Administration and Good Governance (pp. 1-10).

Rahman, S., Rahman, M. (2009). Impact of land fragmentation and resource ownership on productivity and efficiency: The case of rice producers in Bangladesh. Land Use Policy, 26(1), 95-103.

Sauer, J., Davidova, S., Gorton, M. (2012). Land fragmentation, market integration and farm efficiency: empirical evidence from Kosovo. In: 86th Annual Conference, April 16-18, 2012, Warwick University, Coventry, UK (No. 134968). Agricultural Economics Society.

Simmons, A. J. (1964). An index of farm structure, with a Nottingham shire example. East Midl. Geograph., 3, 255-261.

Simpson, S. (1987). Land fragmentation in developing countries: the optional choice and policy implications. Explor. Econ. Hist, 25.

Sklenicka, P. (2016). Classification of farmland ownership fragmentation as a cause of land degradation: A review on typology, consequences, and remedies. Land Use Policy, 57, 694-701.
Sklenicka, P., Janovska, V., Salek, M., Vlasak, J., Molnarova, K. (2014). The Farmland Rental Paradox: extreme land ownership fragmentation as a new form of land degradation. Land Use Policy, 38, 587-593.

Sundqvist, P., Anderson, L. L. (2006), A study of the impacts of land fragmentation on Agricultural productivity in Northern Vietnam. Unpublished Bsc project, Department of Economics. Uppsala University. Sweden.

Tan, S. (2005). Land fragmentation and rice production: A case study of small farms in Jiangam Province, P. R. Chian, Unpublished PhD Thesis, Agricultural Economics Department, Wageningen University.

Tan, S. N., Heerink, G. K., Qu, F. (2008). Do fragmented landholdings have higher production costs? Evidence from rice farmers in Northeastern Jiangxi province, P.R. Land Use Policy, 27(3), 162-179.

Tan, S., Heerink, N., Qu, F. (2006). Land fragmentation and its driving forces in China. Land Use Policy, 23(3), 272-285.

Thapa, S. (2007). The relationship between farm size and productivity: empirical evidence from the Nepalese mid-hills. CIFREM, Austral. J. Agric. Res. Econ., 5(1), 195-211.

Thomas, J. (2007). Property rights, land fragmentation and the emerging structure of agriculture in Central and Eastern European countries. Electr. J. Agric. Dev. Econ., 3(2), 225-275.

Tumer, E. I., Keskin, A., Birinci, A. (2010). Analysis of factors affecting land fragmentation in Erzurum Province, Turkey. Afric. Bus. Manag., 4(8), 1614-1618.

Van Dijk, T. (2003). Dealing with Central European land fragmentation. Delft: Eburon.

Van Hung, P., MacAulay, G., Marsh, S. (2007). The economics of land fragmentation in the North Vietnam. Austral. J. Agric. Res. Econ., 5(1), 195-211.

Weather2 (2017). Local Weather Forecast: Abeokuta Weather Chat. Retrieved 30 $0^{\text {th }}$ April, 2017 from: http://www.myweather2.com/activity/weathermaps. aspx?mapid $=8 \& \mathrm{id}=70992$

World Bank (2005). Land Consolidation Issues in Northern Vietnam - Institutions, Implementation, Impacts. Working Paper, The World Bank.

Wu, Z., Liuand, M., Davis, J. (2005). Land Consolidation and Productivity in Chinese household crop production. China Econ. Rev., 16(4), 28-49. 